\title{
Assessing Effective Utilisation of Instructional Time by Secondary School Teachers in Northern Region, Ghana
}

\author{
Ibrahim Mohammed Gunu (PhD)* \\ Faculty of Education, University for Development Studies, P.O Box 1350, Tamale, Ghana \\ Mohammed Issifu \\ Assistant Headmaster, Ghana Education Service, Business Senior High School, Tamale, Ghana
}

\begin{abstract}
This study investigated teachers' total utilisation of allocated instructional time and its' effects on students learning in Senior High Schools in Northern Region, Ghana. Despite several conceptual and theoretical models regarding the significance of "time" in effective teaching and learning, little is known on how teachers in Ghana spend their time in the school and how the usage varies across SHS in Ghana. This qualitative-case study investigated teacher use of instructional time and draws its validity from Caroll's model of school learning (Carroll, 1963) and Bloom's Mastery learning approach to teaching (Bloom, 1971). The study found that factors that impede total utilisation of instructional time in the selected schools include teacher absenteeism (including maternity and study leave) without alternative arrangement, inadequate preparation, poor teacher-student relationship, teacher involvement in social activities (including social ceremonies) instead of attending to the allotted instructional time, delays at school's events (including Headmaster's assembly), and teachers' attendance to school wide activities (including sporting activities, committee and board meetings). The study therefore recommends effective planning process that accommodates teacher replacement in times of leave, illhealth and other natural phenomenon, and payment of teachers based on instructional time utilisation.
\end{abstract}

Keywords: Effective; Usage; Instructional Time; School

DOI: $10.7176 /$ RHSS/9-2-12

\subsection{Introduction}

Globally effective teaching and learning are critical part of schooling (Kyriacou 2014, 2009; Hayes et al., 2011; Goodall et al. 2005). In order to ensure effective teaching and learning, teachers provide instructions using the designated curriculum content and allotted instructional time for the subject. Leithwood et al., (2010:21) describe the instructional time as 'the potential time left for learning once unplanned events, recesses, transitions, interruptions and the like are subtracted from the total potential time'.

The practices of using the designated curriculum and allotted instructional time are in conformity with the vision of the pre-tertiary teacher education programme in Ghana which aims at making teachers function effectively in the schools (Ministry of Education, 2012). The provision of instructions to students should be directed at ensuring students achievement and general academic success (see Kuh, Bridges and Hayek 2006; Gage, 1991; Cattaneo et al.2016; Gettinger, 1983; Vannest and Hagan-Burke, 2010). This requires that the allocated instructional time should be used effectively.

Total utilisation of the allotted classroom instructional time by the teacher permits the acquisition of the needed values, knowledge, skills and enhancement of the potentials of the teacher (see Ibrahim, 2017; Door, 2014; Brookfield, 2006). The total engagement of students in this sense is significant and costly in the production of education. This kind of engagement provides an Opportunity to learn (OTL). Leithwood et al, (2010:21) describe OTL as 'a targeted version of time actually devoted to instruction which acknowledges that the content or focus of instructional time has significant effect on the nature of student learning'. This concept of learning was first established by Carroll (1963) in his model of school learning (see also Kyriakides, 2011).

Despite the significance of the usage of allocated instructional time and engaged instructional time for effective teaching and learning as well as harnessing the potentials of the nation's resources (see Cattaneo, Oggenfuss and Wolter, 2017; Carroll, 1989; Fisher \& Berliner, 1985; Walberg, 1988) very little accessible discussion of this exists in the context of Ghana.

It is expected that teachers will utilise the instructional time effectively, but we do not know the extent to which these expectations play out in the classrooms and how they may vary across educational institutions in Northern Region of Ghana. This article seeks to address the gap in literature by examining the utilisation of the allotted instructional time in Ghana. In addition, this study is a theorised one drawing on Caroll's model of school learning (Carroll, 1963) and Bloom's Mastery learning approach to teaching (Bloom, 1971). It is hoped that this research will make a significant contribution both to qualitative-case study research approach and to social theoretical analysis in an educational setting.

This article focuses on the usage of allocated instructional time as empirical evidence demonstrates that learning outcomes are linked to the amount of time and efforts students are engaged in learning tasks (see 
Cattaneo et al.2016; Gage, 1991; Carrol, 1963; Bloom, 1971). The concept of time in schooling and teaching is one of the most important variables in improving educational outcomes and ensuring student success (Cattaneo et al.2016). The general notion is that, the exposure of students to good teaching (effective instructional time management) will result in improved academic performance. Lavy (2015) and Woessmann (2003) found that instructional time is positively related to student academic performance.

This is suggestive of the fact that inadequate instructional time and subsequently poor teaching and learning often lead to exam malpractices. The desperate stance of some Ghanaian students to pass at all cost is probably due to lack of confidence in their ability to perform independently in examinations stemming from a host of factors including incompletion of course syllabus which has a bearing on instructional time utilisation in the school setting.

The occurrence of examination malpractices and sometimes the leakage of examination questions in Ghana demonstrates students (and parents) desire to pass examinations through any means available (see Achio, et al., 2012). In the 2011 Basic Education Certificate Examination (BECE), out of the three hundred and seventy thousand, five hundred and eighty-two $(370,582)$ candidates who sat for the examination, one thousand, one hundred and twenty-seven $(1,127)$ of them were involved in malpractices of different dimensions (WAEC, 2012). In the 2012 Basic Education Certificate Examination (BECE), out of 376,859 candidates who sat for the examination, 3,439 of them were involved in malpractices of different dimensions. In the 2013 Basic Education Certificate Examination (BECE), out of 391,079 candidates who sat for the examination, 5,653 of them were involved in malpractices of different dimensions. Similar trend prevails at the secondary school level.

This article focuses on teacher use of instructional time in SHS in Northern Region of Ghana. The research addressed the following research questions in an effort to explore effective utilisation of instructional time in schools.

\subsection{Research Questions}

1. What factors are responsible for teachers' inability to utilise school's instructional time effectively?

2. What effective strategies are available to improve teacher utilisation of instructional time?

\subsection{Contextual Definition of Instructional time}

Drawing on Fisher \& Berliner, (1985), Şimşek (2011) and Bloom (1971) Instructional time can be explained as the time available during school working days which is allocated by school authority for teaching and learning and for the development of the desired behaviuor. Globally, Total instruction time for students aged 15 (which can be likened to Senior Secondary level in Ghana) has an average time of 948 hours among OECD countries. In 2010, France, Germany and England had 1147, 933 and 950 instruction time respectively for students aged 15 (Bruneforth et al., 2015; Hanushek, 1986).

Time helps to regulate the duration for teaching in the classroom. Allocated time allows the content to be delivered within a specified period of time according to GES rules and regulations regarding the number of school days per year and the length of the school day. That is, the time block set aside for a lesson. The duration of periods in Senior High Schools (SHS) is 40 minutes and the duration of the school year is 40 weeks (Annual Senior High School Academic Calendar, 2017/2018). For example, in Second Cycle institutions, mathematics is allocated five periods a week and 40 minutes is allocated for each period/lesson (SHS Syllabus, 2010). Therefore, 200 minutes becomes the weekly allocated time for core mathematics at the Senior High level in Ghana. The actual time available for instruction, however, varies widely.

In all countries, the school calendar is comprehensively constructed with provision made for school/ days and scheduled holidays. Unavoidably, some days will be lost due to unanticipated circumstances, such as weather. In developed countries, schools are prepared for loss of school days/hours resulting from such unforeseen events. In these countries, provisions are made for substitute teachers when needed. However, in lower-income countries, there are no provisions made for disruptions in school days and money for substitute teachers is rarely available. As a result, schools may operate fewer days than expected (see Abadzi, 2007).

\subsection{Method}

This study adopted a qualitative-case study design. The theoretical underpinning of this study hinges on John B. Carrol's model of school learning (Carrol, 1963, 1968; see also Gage, 1991; Shulman, 2008; Gettinger, 1983; Vannest and Hagan-Burke, 2010) and Benjamin Bloom's (1971) Mastery learning approach to teaching (see also Gage, 1991; Elliot, 2001; Shulman, 2008; Gettinger, 1983). These two researchers and theorist agreed that 'the more time students spend in studying, practicing, and being engaged with the content or skills to be learned, the greater the related learning they achieved' (Gage, 1991:279-280).

The validity of Carroll's model (1963) has been confirmed by several research studies and meta-analysis in the area of instructional time utilisation in the classroom (see Kyriakides, 2011; Elliot, 2001; Gage, 1991; Shulman, 2008; Gettinger, 1983; Vannest and Hagan-Burke, 2010). Also, Bloom theory of 'mastery learning' 
which is drawn from Carrol's model of school learning (see Carrol, 1963) indicates that 'the greater majority of students, say 90 - 95 per cent, are able to learn basic principles, concepts and skills - if they are given enough time' (Husén, 2001:86-7). This means that privileged students from privileged homes and schools who have had the opportunity to benefit from private individual organised instruction and school monitored usage of allocated instructional time get enough time to master the learning task, this can lead to better achievement (see Husén, 2001). It also shows that time is an important component in the production of education.

In this study forty research participants were purposively selected from four senior high schools in four Metropolitan/Municipal/District assemblies in Ghana for interviews. These included 24 teachers, 4 assistant headmasters academic, and 12 students. The teachers met the following criteria for inclusion: (i) professionally trained teachers (ii) full-time teachers in a state-owned secondary school in Ghana.

It was essential that any approach that the article adopted was qualitative in nature, as the interviews provided an in-depth understanding of teacher use of time in classroom interactions and allowed a triangulation of the teachers' narration with students' experience of how the instructional time is utilised in the classroom. The study also employed the triangulation of theory (see Yin, 2018; Creswell, 2013; Neuman, 2011; Bryman, 2015) as Carrol's (1963) theoretical work of school learning (Carroll, 1963) is used together with Bloom's (1971) theory on Mastery learning approach to teaching (Bloom, 1971). These were the lenses through which the social phenomenon was viewed and analysed.

The four Metropolitan/Municipal/district areas; Tamale Metropolis, Sagnarigu Municipality, Karaga and Gushegu Districts, where the research was conducted were chosen based on the following issues: proximity to the researchers, and differences in socio-economic factors. School C and D were situated in rural areas and had a greater number of less educated parents, economically disadvantaged students and less ethnically diverse, whilst school A and B were situated in urban areas and served students who were more ethnically diverse, economically advantaged and had well-educated parents. These differences were key in presenting wellgrounded empirical studies. In the following the findings and discussions of the data are presented.

\subsection{Findings and Discussion}

This section presents the findings and the discussions of the research. Generally, the respondent teachers' years of teaching experience ranged from 1 year to 25 years. The highest qualification earned by these teachers ranged from HND to postgraduate (masters). Two teacher participants had HND, eighteen held bachelor's degrees, and four held master's degrees.

\subsection{Factors Responsible for Teachers' inability to Utilise Instructional Time Effectively}

Differences in time utilisation was reported across all the four schools in the region. In school A for example five of the respondents interviewed missed 9 periods of their lessons within the 4 weeks reference period representing 360mins of instructional time. In school B five of the respondents interviewed missed 16 periods of their lessons within the 4 weeks reference period representing 640mins of instructional time. In school $\mathrm{C}$ five of the respondents interviewed missed 21 periods of their lessons within the 4 weeks reference period representing 840 mins of instructional time and in school D five of the respondents interviewed missed 23 periods of their lessons within the 4 weeks reference period representing 920mins of instructional time. Within the context of economics of education these losses have budgetary implications for the nation.

The study identified the following as constituting the reasons accounting for the teachers' inability to utilise instructional time effectively. These factors are; teacher absenteeism leading to loss of contact hours, inadequate preparation, family demands and child bearing and other interruptions.

In the following the article focuses on the factors precipitating loss of instructional time in the school;

\section{i. Teacher absenteeism leading to loss of contact hours;}

Twenty out of 24 teachers, 10 out of 12 students and 4 school leaders interviewed indicated that some teachers were absent in school during the hours of their lessons. In school A the subject teachers identified include Social studies, Physical Education and Economics. In school $\mathrm{C}$ the subject teachers identified include Integrated Science, Costing, English, Core Mathematics and Economics. In school B the subject teachers identified include ICT, P.E., English, Core mathematics and Financial Accounting and in school D the subject teachers identified include Social studies, Physics, Integrated Science, mathematics and History. A member of school management indicated that:

$$
\text { “... sometimes, teachers are unable to honor their lessons ...” (TA 02). }
$$

Teachers provided the following reasons for Absenteeism; breakdown of means of transport, ill-health, attendance of social occasions such as funerals, and naming ceremonies; attendance of workshops, private businesses, District Assemble meetings, going to Bank, and other school meetings, among others.

The lost contact hours resulting from the absence of the teacher in class could have negative impact on student learning as it could lead to students' low academic performance (see Abadzi, 2007, 2009; Walberg, 1988). Available evidence shows that when a teacher is repeatedly absent during lessons time in the classroom 
learning and student performance are impacted negatively (see Abadzi, 2007, 2009; Walberg, 1988).

Carroll's findings regarding the fact that student achievement is an outcome of the amount of time a learner is engaged in learning activities (see Fisher \& Berliner, 1985; Walberg, 1988) sends a signal that reduced instructional time accumulated over time puts students, especially those from low-income communities at a risk of underachievement and possible school dropout (Grissom, Loeb, And Master, 2013; Walberg, 1988; Abadzi, 2007, 2009;). The findings of this research suggest that teacher absenteeism was highly prevalent in the lowincome and rural communities where parents of these students are less educated.

The findings of this research therefore bring into sharp focus issues of equity most especially as the government of Ghana implements the free SHS programme for purposes of access, equity among others (see Gunu, 2018). Researchers identified instructional time as a significant issue in schooling therefore its appropriate allocation is deemed necessary in the daily activities of the school (see Blank, 2013; Gettinger, 1985; Karweit, 1983). It is through the allocated instructional time that the opportunity to learn (see Carrol, 1963) is created.

The study further revealed that teachers organise extra tuition to make up for missed lessons. However, some respondents reported that they paid for some of the extra tuition organised for them. Testimonies of respondents are presented below:

“... But we pay for the extra tuition” S3

"... But the biology teacher asked us to pay for the extra tuition" (S1)

It is suggestive of the fact that teachers refuse to use the normal instructional hours but prefer to provide extra tuition at extra cost, meaning they take double reward for the same work.

In Ghana the Public Services Commission Report, (2015), reported a $57.4 \%$ absenteeism of staff misconduct recorded in the public service of Ghana and that $61.2 \%$ of these misconducts attracted queries or warning letters. Teacher absenteeism affects the utilisation of instructional time in schools (Abadzi, 2007, 2009). In some cases the absence of the teacher occurs when $\mathrm{s} / \mathrm{he}$ chooses to allocate his/her time to activities that compete with scheduled school work (Fichman, 1984).

Teacher absenteeism has serious implications on the Ghanaian economy as the unit labour cost in the production of education in Ghana considers the required instructional time in the classroom per teacher. In the face of the rising wages and in the interest of economic growth and sustainability, it will be prudent for economic measures to be taken that may include deducting the lost instructional time from the base pay. This can potentially improve work place practices regarding the use of the allocated time, productivity and cost effectiveness in the education sector (see Brown and Armstrong, 1999).

\section{ii. Inadequate Preparation, lateness and laziness}

The study established that inadequate preparation for lessons on the part of teachers also accounted for teachers' ineffective use of instructional time. Four respondents out of the twenty-four teacher respondents stated that teachers are not able to fully utilise instructional time allocated to lessons as a result of inadequate preparations and laziness. Responding to the question why teachers are not able to utilise allocated instructional time, two teachers stated:

$$
\begin{aligned}
& \text { “... due to inadequate preparation for lessons" (T3) } \\
& \text { "... laziness". (T12) }
\end{aligned}
$$

Time is an important variable and costly resource in education production (see Carrol, 1963; Cattaneo, Oggenfuss and Wolter, 2017; Vannest and Hagan-Burke, 2010), therefore it must be used effectively and judiciously.

\section{iii. $\quad$ Family Demands and Child Bearing}

The study revealed that teachers' inability to utilise instructional time effectively was also influenced by demands on teachers as parents and child bearing mothers. In the views of some respondents, teachers with children of school going age often send their children to school before coming to school to honor their lessons; teachers' responsibilities to their families. In such instances, teachers who have morning lessons mostly miss their lessons or come to the class late. The responses of the respondents suggest that families depend on teachers for some services such as sending/picking children to school and family members for health care services; such activities affect teachers' presence in class and therefore affects the utilisation of instructional time.

Also, child bearing, and maternity leave were other factors identified in the study as affecting use of instructional time. A nursing mother on maternity leave is hardly replaced by Ghana Education Service (G.E.S)/school management. A student stated in the following:

"Our food and nutrition teacher gave birth, ... since then, no teacher has come to honor her lesson ...." (S10).

The research findings suggest that the demands of child bearing on female teachers and the granting of maternity leave to teachers without replacing the regular teacher on maternity leave affects student learning and achievement. The rate of student learning or achievement is related to the proportion of the actual time spent on a learning task (Carroll, 1989; Park, Jung and Reeves, 2015). 


\section{iv. Teacher-students Relationship in the classroom}

Teacher-student conflict has been the challenge affecting teacher-student relationships in some of the selected schools. This affects the classroom environment as in this circumstance the teacher devotes most of the instructional time to manage student behaviour. CPD programmes on anger coping skills will help address some of these challenges (Hemphill and Hargreaves, 2009; Rogers, 2015; Ibrahim, 2017). The following excerpts demonstrate this point clearly:

'... sometimes students misbehave to annoy the teacher' 58

'I am not able utilise the full instructional time in some cases because of lack of cooperation from students ...' '

Good teacher-student relationship will help build great confidence in the students and inspire them to express kind gestures towards the teacher. The teacher's conduct sets the tone for the classroom environment (Thompson \& Sharp, 1994; Burton and Chapman, 2012; Ibrahim, 2017).

\section{v. Inadequate TLMS}

The absence of Teaching-Learning materials (TLMs) especially white board makers and chalk in two of the selected schools affected the full utilisation of allocated instructional time. Wide range of research suggests that instructional time is a fundamental condition for teaching and learning (see Corey, et al., 2012; Carrol, 1963, Bloom, 1971) therefore its wastage will affect the production of education in Ghanaian High Schools.

\section{vi. Use of mobile phone in the classroom}

Some teachers receive phone calls whilst teaching this affects the effective utilisation of instructional time. Using the time for its rightful purposes should be the order in the senior high schools. School time plays in efforts to improve students' opportunities to learn (Corey, et al., 2012), therefore the time must be utilised for its rightful purpose.

\section{vii. Related interruptions emanating from other school activities}

From the study, it was found that other activities in the school affects the use of instructional time. These factors include delays at assembly on Mondays, delays during break periods, sporting activities and other unprogrammed activities that take teachers or students out of the class during instructional hours. Excerpts of responses confirming the effect of such interruptions on instructional time use is presented below:

"Monday morning assembly consumes part of the time ..." (T7).

The unprogrammed ways in which time is used in Ghanaian High Schools finds stances in Bloom's (1971) agreement with Carroll's (1963) assertion that "the greatest barrier to student learning is the insane way in which we use time" Shulman (2008:1). The way time is used in Ghanaian High Schools needs a constructive change.

\subsection{Assessing Work Load on Teachers}

Based on the number of contact periods per class in a week, the work load on teachers was then derived. From the responses of the teachers in school A, the minimum weekly work load among the respondent was 3 periods (120mins) and the maximum instructional hours was 20 periods ( $800 \mathrm{mins})$. In school $\mathrm{B}$, the minimum weekly work load among the respondent was 4 periods (160mins) and the maximum instructional hours was 20 periods (800mins). In school $\mathrm{C}$, the minimum weekly work load among the respondent was 4 periods (160mins) and the maximum instructional hours was 20 periods (800mins) and in school D, the minimum weekly work load among the respondent was 3 periods (120mins) and the maximum instructional hours was 48 periods $(1,920 \mathrm{mins})$. According to the Ghana Education Service regulations, a teacher in a second cycle institution is required to teach a minimum of 16 hours ( 24 periods) and a maximum of 21 hours ( 32 periods) in a week. From the above information it is evident that most of the respondents are teaching below the minimum weekly instructional workload.

\subsection{Effective Strategies to Improve the Utilisation of Instructional Time by Teachers}

Based on the findings of the research the following strategies will assist improve the utilisation of instructional time in Ghanaian High Schools:

\section{Effective Planning}

Effective planning process makes execution of tasks much easier and relatively successful (see Mintzberg, 2009; Storey, Wright, and Ulrich, 2009; Greenwait, 2002; Piggot, 2000; Torrington, 1989). This kind of planning is one of the fundamental principles of management which creates room for deciding in advance what to be done thereby reducing the risk of failure or related challenges (see Mintzberg, 2009; Storey, Wright, and Ulrich, 2009; Greenwait, 2002; Piggot, 2000; Torrington, 1989; Fiore, 2006). In keeping with this planning, the school should take into consideration the planning of the academic colander that takes into consideration non-academic and academic instructional times.

\section{Strategic behaviour management skills}

Behaviour Management skills is a significant aspect of schooling that helps to maintain good classroom environment which permits effective utilisation of the instructional time in schools (see Ibrahim, 2017; Kyriacou 2014; Hayes et al., 2011; Strahan 2005; Walby 1998;). An effective classroom environment enhances time 
management and maximises engagement rates.

\section{Effective supervision of instructional time utilisation}

Headteachers of various SHS should ensure effective monitoring and supervision of instructional time utilisation in the classroom. This will enhance teacher accountability, teaching and learning. Glickman, et al (2004) point out that instructional supervision practices have the potential to improve classroom instruction and encourage teachers to provide supportive and task-oriented learning environment (Rogers 2015; Kyriacou 2014; Haydn, 2012; Jambor, 1998).

\section{Continuous use of siren/loud speakers to announce the beginning and end of lessons}

The study revealed that the use of siren/loud speakers is an appropriate strategy adopted in enhancing the use of instructional time in the schools. Loud speakers are mounted in the school and connected to a programmed device that announces the daily scheduled activities at specific time periods.

\section{Use of technological device to monitor attendance}

Some respondents suggested the introduction of a technological device in monitoring teacher attendance and performance. A teacher expressed this concern in the following excerpts:

“... design a system to capture time of entry and exit of teachers in classrooms and ... effective monitoring and evaluation of teaching and learning in classrooms'. ... The existence of ... time records will make teachers effective as they are conscious of regular monitoring" (T10).

This shows the willingness of some teachers to be accountable in the performance of their duties.

\section{Decentralisation teacher sanctioning, hiring and firing}

Some respondents suggested that schools should be empowered to sanction teachers who miss their lessons deliberately without referring them to the Metropolitan/District Directorate of Education for sanction. This article argues that teacher hiring and firing as well as verification for payment should be done at the school level.

\section{Policy implication of the findings}

The findings of the research is suggestive of the fact that, the educational policy text (see Ball, 1993, 1994; 2013; Halpin and Troyna, 1995) in Ghana should take into consideration payment policies that allow payment to be made based on the instructional time utilised by the teacher, and the validation of payment of monthly salary at the school level. Also, alternative arrangement should be readily available for individuals to take up teaching responsibility in times of leave and other forms of teacher absenteeism in school. The related policy effects (see Ball, 1993, 1994; 2013; Halpin and Troyna, 1995) could be that instructional time will be fully utilised and there will increase learning outcomes.

Vital school resources such as available instructional time should be utilised judiciously, this potentially will enhance the efficiency of the current educational system. This makes classroom instructional time one of the significant educational factors with policy relevance. Benavot (2004) states that instructional time utilisation increases student rate of achievement regarding the learning task. . Despite the fact some researchers raise doubts about the impact of more instructional time (e.g. Karweit 1978), the acknowledged benefits of instructional time have gained considerable prominence among national and international policy engineers.

\subsection{Limitations and Suggestions for Further Research}

This study looked at the utilisation of allocated instructional time across the four schools in four weeks within one academic term. Differences may exist across the yearly academic calendar and time usage in this academic term (the term in which the research was conducted) may not be reflective of what happens in the other academic terms. There are also limitations in generalisability to large numbers of teachers, when only 24 teachers, 4 members of school leadership and 12 students were interviewed in this study. Further, the research was interested in establishing time usage; the time that teachers would typically be working in the classroom was the focus without considering quality usage of the time. In addition, research regarding quality utilisation of instructional time in the classroom will help minimise teacher presenteeism in the Ghanaian schools. Further research on instructional time utilisation should also expand the sample to cover many schools and should be done throughout the academic calendar.

\section{Conclusion}

This article focuses on the full utilisation of the allocated instructional time in SHS in Ghana. The study revealed several factors leading to the wastage of instructional time key among them include teacher absenteeism, lateness, presenteeism, and delays at school unprogrammed functions. These incidences were more predominant in the rural schools than in the urban areas. Currently, the non-instructional time demarcated include breaks, general holidays and examinations periods. It is hoped that the rates of non-utilisation of instructional time would be minimised if the teachers are paid based on the utilisation of the allocated instructional time, preventing continuous absentee teachers from drawing salaries, monthly validation of salary payment from the schools, making alternative staff arrangements for teachers who cannot be present for classroom lessons, allowing school committees and board meetings to be held after class hours, organising CPD programmes on 
effective instructional time utilisation for teachers and planning of the academic calendar mapping out noninstructional hours for school-wide activities (like sporting activities, headmaster's Assembly etc.).

\section{References}

Abadzi, H. (2009). Instructional Time Loss in Developing Countries: Concepts, Measurement, and Implications. The World Bank Research Observer, 24(2), pp. 267-290.

Abadzi, H. (2007). Absenteeism and beyond: instructional time loss and consequences. The World Bank.

Achio, S., Ameko, E., Kutsanedzie, F., Alhassan, S. and Ganaa, F. (2012). Concerns on issues of examination malpractices a case study of Accra Polytechnic. Academic Research International, 3(2), p.145.

Annual Senior High School Academic Calendar, 2017/2018(n.d). Ghana Education Service.

Ball, S.J. (1993). Education policy, power relations and teachers' work'. British Journal of Educational Studies, 41(2), pp.106-121.

Ball, S.J. (1994). Education reform a critical and post-structural approach. Buckingham: Open University Press. Ball, S.J. (2013). The education debate. 2 edn. Bristol: Policy.

Benavot, A. (2004). A Global study of intended instructional time and official school curricula, 1980-2000. Paper commissioned for the EFA Global Monitoring Report 2005, The Quality Imperative.

Blank, R.K. (2013). Science Instructional Time Is Declining in Elementary Schools: What Are the Implications for Student Achievement and Closing the Gap? Science Education, 97(6), pp. 830-847.

Bloom, B. S. (1971) Mastery learning, in: J. H. Block (ed.) Mastery learning: theory and practice. New York: Holt, Rinehart \& Winston.

Brookfield, S.D. (2006). The skillful teacher; on technique, trust, and responsiveness in the classroom. 2 edn. San Francisco, CA: Jossey-Bass.

Burton, L. and Chapman, D. (2012). Does increasing instructional time lead to higher student achievement? Evidence from India. Asian Education and Development Studies, 1(3), pp. 208-221.

Bruneforth, M., Chabera, B., Vogtenhuber, S. and Lassnigg, L. (2015). OECD Review of Policies to Improve the Effectiveness of Resource Use in Schools: Country Background Report for Austria.

Bryman, A. (2015). Social Research Methods. 5th edn. Oxford: Oxford University Press.

Carroll, J. B. (1963). A model of school learning. The Teachers College Record, 64, 723-733.

Carroll, J. B. (1968). Presidential address of division 15 on learning from being told. Educational Psychologist, $5(2), 1-10$.

Carroll, J. B. (1989). The Carroll model: A 25-year retrospective and prospective view. Educational Researcher, $18,26-31$

Cattaneo, M.A., Oggenfuss, C. and Wolter, S.C. (2017). The more, the better? The impact of instructional time on student performance. Education economics, 25(5), pp.433-445.

Corey, D., Phelps, G., Ball, D., Demonte, J. and Harrison, D. (2012). Explaining Variation in Instructional Time: An Application of Quantile Regression. Educational Evaluation and Policy Analysis, 34(2), pp. 146.

Creswell, J. W. (2013). Qualitative inquiry and research design; choosing among five approaches. 3 edn. Los Angeles: SAGE Publications.

Door, V. (2014). Developing creative and critical educational practitioners. St Albans: Critical Publishing.

Elliot, J. (2001). Making evidence-based practice educational. British Educational Research Journal, Vol. 27, No.5, 2001, pp.555-74

Fiore, A. (2006). The Now Habit: A strategic programme for overcoming procrastination and enjoying guilt-free play. New York: Pengnium Group.

Fisher, C. W., \& Berliner, D. C. (Eds.) (1985). Perspectives on instructional time. New York: Longman

Gunu, M. I. (2018). Alternatives to School Exclusion in Ghana: Changing the Rhythm of Dealing with Truancy in Ghanaian High Schools. SAGE Open, 8(4), p.2158244018805361.

Goodall, J., Day, C., Lindsay, G., Muijs, D. \& Harris, A. (2005). Evaluating the impact of continuing professional development (CPD) (No. Reference: RR659). London: Department for Education and Skills.

Gage, N. (1991). The obviousness of social and educational research results. Educational Researcher, Vol. 20, no.1, 10-16.

Gettinger, M. (1983). Effects of Learner Ability and Instructional Modifications on Time Needed for Learning and Retention. The Journal of Educational Research, 76(6), pp. 362-369.

Grissom, J., Loeb, S. and Master, B. (2013). Effective Instructional Time Use for School Leaders: Longitudinal Evidence From Observations of Principals. Educational Researcher, 42(8), pp. 433.

Glickman, C.D., Gordon, S. P., \& Ross-Gordon, J. M. (2004). Supervision and Instructional leadership: A developmental approach. New York, NY: Pearson

Greewait, J. F. (2002). Managing your time, energy and talent in ministry. New York: Fathers and Brothers of S \& Pau.

Ghana Government Education Strategic Plan 2010 To 2020: Policies, Strategies, Delivery, Finance (N.D). 
Ministry of Education, February 2012.

Halpin, D. \& Troyna, B. (1995). The Politics of Education Policy Borrowing. Comparative Education, 31(3), pp. 303-310.

Hanushek, E.A. (1986). The economics of schooling: Production and efficiency in public schools. Journal of economic literature, 24(3), pp.1141-1177.

Hayes, B., Richardson, S., Hindle, S. and Grayson, K. (2011). Developing teaching assistants' skills in positive behaviour management: an application of Video Interaction Guidance in a secondary school. Educational Psychology in Practice, 27(3), pp.255-269.

Haydn, T. (2012). Managing pupil behaviour; improving the classroom atmosphere.2ed. Abingdon: Routledge.

Husén, T. ( 2001). 'Benjamin S. Bloom 1913-99', in L. Bresler, D. Cooper, and J. Palmer, (eds). Fifty modern thinkers on education: From Piaget to the present. Oxon: Routledge, pp.86-90.

Ibrahim, M.G. (2017). "Perspectives on student behaviour management in High Schools in Ghana: exploring potential for positive behaviour management in policy and practice" Vols 1 and 2. PhD Thesis, Keele University, UK.

Jambor, T. (1988). Classroom Management and Discipline Alternatives to Corporal Punishment: The Norwegian example. Education, 109(2), pp.220-225.

Kamens, D.H., Meyer, J.W. and Benavot, A. (1996). Worldwide patterns in academic secondary education curricula. Comparative education review, 40(2), pp.116-138.

Karweit, N. L (1976). A reanalysis of the effect of quantity of schooling on achievement. Sociology of Education, 49, 235-46.

Karweit, N. L. (1983). Time-on-task: A research review. Report No. 332. Baltimore Johns Hopkins University, Center for Social Organization of Schools.

Kuh, G. D., Bridges, B. K., and Hayek, J. C., (2006). What Matters to Student Success: A

Review of the Literature. Commissioned Report for the National Symposium on

Postsecondary Student Success: Spearheading a Dialog on Student Success.

Kyriacou, C. (2009). Effective teaching in schools: theory and practice. 3 edn. Cheltenham: Nelson Thornes.

Kyriacou, C. (2014). Essential teaching skills. Fourth edn. Oxford: Oxford University Press.

Kyriakides, L. (2011). Advances in school effectiveness theory, in C. Chapman, P. Armstrong, A. Harris, D. Muijs, D. Reynolds and P. Sammons (eds) School Effectiveness and Improvement Research, Policy and Practice. London: Routledge.

Lavy, V. (2015). Do differences in schools' instruction time explain international

achievement gaps? Evidence from developed and developing countries. The Economic Journal, Volume 125, Issue 588, F397-F424.

Leithwood, K., Anderson, S. E., Mascall, B., and Strauss, T. (2010). 'School Leaders Influences on Student Learning: The Four Paths', in T. Bush, L. Bell and D. Middlewood (eds), The principles of educational leadership and management. 2nd ed. London: Sage Publications, pp.13-27.

Mintzberg, H. (2009). Strategy safari: the complete guide through the wilds of strategic management. 2nd ed. Harlow: Financial Times Prentice Hall.

Neuman, W. L. (2011) Social Research Methods: Qualitative and Quantitative Approaches. $7^{\text {th }}$ edition. Boston: Allyn \& Bacon.

OECD (2014). Education at a Glance (OECD Publishing, Paris).

Park, Y., Jung, I. and Reeves, T.C. (2015). Learning from MOOCs: a qualitative case study from the learners' perspectives. Educational Media International, 52(2), pp. 72-87.

Piggot, C. S. (2000). Business planning for healthcare management. 2nd ed. Buckingham England]; Philadelphia: Buckingham England; Philadelphia: Open University.

Public Services Commission, Ghana (2015). State of the Public Service Report of Ghana.

Rogers, B. (2015). Classroom behaviour: a practical guide to effective teaching, behaviour management and colleague support. 4th edn. Thousand Oaks, CA: Sage Publications.

Shulman, L. (2008). It's All About Time! The Hispanic Outlook in Higher Education, 18(11), pp. 21.

Şimşek, A. (2011). Ogretim Tasarımı. [Instructional design]. Ankara: Nobel.

Storey, J., Wright, P.M. And Ulrich, D. (2009). The Routledge companion to strategic human resource management. London: London: Routledge.

Strahan, D.B., Cope, M.H., Hundley, S. and Faircloth, C.V. (2005). Positive Discipline with Students Who Need It Most: Lessons Learned in an Alternative Approach. Clearing House: A Journal of Educational Strategies, Issues and Ideas, 79(1), pp.25-30.

Torrington, D. (1989). Effective management: people and organisation. London: London: Prentice Hall.

Thompson, D. \& Sharp, S. (1994). Improving schools establishing and integrating whole school behaviour policies. London: London David Fulton.

Vannest, K.J. and Hagan-Burke, S. (2010). Teacher Time Use in Special Education. Remedial and Special 
Education. March 2010, Vol. 31(), pp.126-142.

Walby, C. (1998). The National Commission of Inquiry into the Prevention of Child Abuse: will it make a difference? Child Abuse Review, 7(2), pp.77-86.

Walberg, H. J. (1988). Synthesis of research on time and learning. Educational Leadership, 45(6), 76-85.

West African Examination Council (2014). Latest WACE syllabus for all subjects (SSCE,

GCE) - 2015. Retrieved on November 24, 2014 from http://www.myschoolgist.com/ng/waec-syllabus-bysubject-2013.

Woessmann, L. (2003). Schooling resources, educational institutions and student performance: The international evidence. Oxford Bulletin of Economics and Statistics, 65, 117-170.

Yin, R. K. (2018). Case study research and applications: Design and methods (6th ed.). Los Angeles, CA: Sage Publications.

\section{Author Biography}

Ibrahim Mohammed Gunu is a lecturer and postgraduate programmes coordinator at Faculty of Education, University for Development Studies, Tamale, Ghana. He holds Bachelor of Education (Primary Education) from University of Cape Coast, Ghana. He attained his Master of Arts (Adult Education) from University of Ghana and $\mathrm{PhD}$ in Education from Keele University, England. He is a Commonwealth Scholar. His areas of expertise and interest include Continuous Professional Development of workers, Educational Management and Policy Studies (including policy enactment) design, implementation and assessment of evidence-based educational programmes for both children and adults.

\section{Author Biography}

Mohammed Issifu is a teacher and an Assistant Headmaster at Business Senior High School, Tamale, Ghana. He holds a Bachelor of Education (Psychology) from the University of Cape Coast, Ghana. He attended University for Development Studies, Tamale, for his Master of Philosophy (Training and Development). His areas of interest include Continuous Professional Development of workers/Training and Development and Educational Management issues. 